\title{
Spectrophotometric Determination of Urinary Protein with $o$-Sulfophenylfluorone-Metal Complex
}

\author{
Takako Yamaguchi, Emi Amano, Shinichiro Kamino, Satoko Umehara, Chizuko Yanaihara, and \\ Yoshikazu FuJıTA ${ }^{\dagger}$
}

Osaka University of Pharmaceutical Sciences, 4-20-1, Nasahara, Takatsuki, Osaka, Japan

\begin{abstract}
A simple and sensitive spectrophotometric method for the determination of human serum albumin (HSA) was established based on the ternary complex-formation reaction of HSA with $o$-sulfophenylfluorone (SPF) as a xanthene dye and metal ion (niobium $(\mathrm{V})$ and bismuth(III)) in the presence of a dispersion agent. This new method enabled the determination of HSA in the range of $1-15 \mu \mathrm{g} / \mathrm{ml}$ HSA by measuring the difference of the absorbance at $530 \mathrm{~nm}$ between HSA-SPFmetal ion and SPF-metal ion solutions. In the determination of HSA, this method is about 2-times more sensitive than the Pyrogallol Red-molybdenum(VI) method (PR method), which accounts for more than $80 \%$ of the quantification methods for urinary protein assays in Japan. There was no significant difference between the results obtained by the present method and the PR method for human urine samples. The binding process between the SPF-metal complex and HSA was studied by determining the binding parameters and the thermodynamic parameters.
\end{abstract}

(Received July 4, 2005 ; Accepted August 15, 2005)

The quantification of protein in body fluids is one of the important long-standing clinical tests; the urinary protein test, which is non-invasive and does not burden patients, is the most common routine test used in many institutions for readily examining kidney diseases. In addition, it has recently been recognized that microalbuminurea (i.e., a urinary albumin excretion rate of 20 to $200 \mu \mathrm{g} / \mathrm{min}$ ) is closely related to metabolic syndrome, such as cardiovascular disease, hypertension and diabetes. ${ }^{1,2}$

During several decades, turbidimetry methods, such as the Kingsbury-Clark method ${ }^{3}$ and the Meulemans method, ${ }^{4}$ have been widely used for urinary protein assay by measuring turbidity produced by the reaction of protein with sulfosalicylic acid. However, these methods had serious disadvantages: differences in turbidity among proteins; difficulty in adaptation to autoanalyzers, inadequacy to sulfosalicylic acid-soluble proteins, and considerable differences among institutions. Furthermore, lesions are often already in the irreversible stage when they are detectable by the method due to low sensitivity. Therefore, instead of turbidimetry, a simple and highly sensitive method for a routine test of urinary proteins was needed. To solve these problems of turbidimetry, we developed the Pyrogallol Red-molybdenum(IV) complex method (PR method). ${ }^{5}$ The PR method ${ }^{5-7}$ is currently the most popular method, and accounts for more than $80 \%$ of the quantification methods for urinary protein in Japan.

However, the PR method has drawbacks in the reactivity among proteins, especially a low reactivity to Bence-Jones protein, which is significantly increased in B cell tumor proliferative diseases, such as multiple myeloma and chronic lymphocytic leukemia, a slightly long reaction time, and poor

$\dagger$ To whom correspondence should be addressed.

E-mail: fujitay@gly.oups.ac.jp

A part of this work was presented at the 65th Symposium on Analytical Chemistry, Okinawa, 2004. reproducibility at a low concentration of protein.

These problems would cause the combination of dyes, metal ions and/or surfactants as a dispersion agent on the formation of the HSA-dye-metal ternary complex. Considering the HSAB rule, Irving-Williams ranking, electric charge, and coordination number of the metal ion led to selecting acidic xanthene dyes with a sulfonic acid group that have high metal ion complexforming abilities.

In a continuation of our investigations, we found that the response of the $o$-sulfophenylfluorone (SPF)-metal (niobium(V) and bismuth(III)) complex to HSA was considerably sensitive. SPF is a structural isomer of PR and belongs to 9-R-2,3,7trihydroxy-6-fluorones. Here, we report on a new, simple and sensitive spectrophotometric method for the determination of HSA by forming a SPF-metal complex; the proposed method was applied to urinary protein assays. In addition, a binding process of the ternary complex in this reaction system among SPF, metal ion and HSA was studied by using a van't Hoff plot, and so on.

\section{Experimental}

Apparatus, reagents and solutions

Apparatus. A Shimadzu spectrophotometer (Model UV-160) with $1.0-\mathrm{cm}$ matched silica cells was used for absorbance measurements. The $\mathrm{pH}$ measurements were made with a Horiba (Model F-11) $\mathrm{pH}$ meter equipped with a combined glass electrode.

Reagents and solutions. A standard HSA solution $(100 \mu \mathrm{g} / \mathrm{ml})$ was prepared by dissolving human serum albumin (essential fatty acid-free, Fraction V, purchased from Sigma Chemical Co. $)$ in water. A solution $\left(1.0 \times 10^{-3} \mathrm{~mol} \mathrm{dm}^{-3}\right)$ of SPF, which had been synthesized according to a method described in the literature, ${ }^{8}$ was prepared by dissolving SPF in methanol. A metal-ion solution was a mixed solution of $5.0 \times 10^{-4} \mathrm{~mol} \mathrm{dm}^{-3}$ 


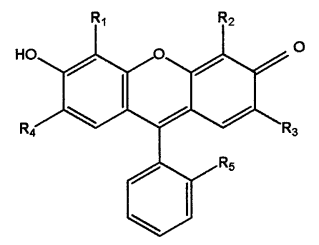

\begin{tabular}{c|ccccc} 
& $\mathrm{R}_{1}$ & $\mathrm{R}_{2}$ & $\mathrm{R}_{3}$ & $\mathrm{R}_{4}$ & $\mathrm{R}_{5}$ \\
\hline $\mathrm{SPF}$ & $\mathrm{H}$ & $\mathrm{H}$ & $\mathrm{OH}$ & $\mathrm{OH}$ & $\mathrm{SO}_{3} \mathrm{H}$ \\
PR & $\mathrm{OH}$ & $\mathrm{OH}$ & $\mathrm{H}$ & $\mathrm{H}$ & $\mathrm{SO}_{3} \mathrm{H}$ \\
$\mathrm{BPR}$ & $\mathrm{OH}$ & $\mathrm{OH}$ & $\mathrm{Br}$ & $\mathrm{Br}$ & $\mathrm{SO}_{3} \mathrm{H}$ \\
$\mathrm{QP}$ & $\mathrm{H}$ & $\mathrm{H}$ & $\mathrm{OH}$ & $\mathrm{OH}$ & $\mathrm{COOH}$ \\
PF & $\mathrm{H}$ & $\mathrm{H}$ & $\mathrm{OH}$ & $\mathrm{OH}$ & $\mathrm{H}$
\end{tabular}

Fig. 1 Structures of dyes.

of niobium(V) and $5.0 \times 10^{-4} \mathrm{~mol} \mathrm{dm}^{-3}$ of bismuth(III), prepared by diluting a niobium and bismuth standard (Wako Pure Chem. Co. Ltd., $1000 \mu \mathrm{g} / \mathrm{ml})$. A mixed solution of a $0.75 \%$ solution of poly(vinyl alcohol) (3500, Wako Pure Chem. Co. Ltd.) and $0.25 \%$ arabic gum (Kishida Chem. Co. Ltd.) in the final concentration was used as a surfactant. A buffer used for this work was prepared by mixing $0.1 \mathrm{~mol} \mathrm{dm}^{-3}$ hydrochloric acid and $0.1 \mathrm{~mol} \mathrm{dm}^{-3}$ sodium citrate solutions. All other reagents and materials used were of analytical reagent grade unless otherwise noted. Pure water was prepared by purifying deionized water with a Milli-Q Labo system just before use.

\section{Standard procedure for the determination}

The following components were mixed in a $10 \mathrm{ml}$ volumetric flask: $0.5 \mathrm{ml}$ of a metal ion solution, $1.0 \mathrm{ml}$ of a surfactant solution, $2.0 \mathrm{ml}$ of buffer, $1.0 \mathrm{ml}$ of an SPF solution, and a solution containing serially diluted HSA. The mixture was mixed well, and then made up to volume with water, transferred into a test tube, and kept at room temperature for $10 \mathrm{~min}$. The absorbance of the resulting solution was measured at $530 \mathrm{~nm}$ against a reagent blank prepared in the same way without HSA.

\section{Results and Discussion}

\section{Choice of dye and metal ion}

We preliminarily examined the utility of a method for determining HSA by comparing the coloration using several dyes and metal ions at various $\mathrm{pH}$ values $(c a . \mathrm{pH} 1-8)$. A HSA-dye-metal solution without a surfactant precipitated gradually. The use of a non-ionic surfactant was effective as a dispersion agent. The effect of dyes was studied by measuring the absorbance of a HSA-dye-metal ion solution against a dyemetal solution. The dyes used were SPF, PR, Bromopyogallol Red (BPR), o-hydroxyhydroquinonephthalein (QP) and phenylfluorone (PF) (Fig. 1). These dyes could be arranged in the following order with respect to the sensitivity: $\mathrm{SPF} \gg \mathrm{BPR}$, $\mathrm{PR}>\mathrm{QP}>\mathrm{PF}$. A HSA-SPF-metal ion solution in the presence of a non-ionic surfactant exhibited a considerable red shift compared to an SPF-metal solution in an acidic medium. The effectiveness of different metal ions at various $\mathrm{pH}$ values was compared by measuring the absorbance of a HSA-SPF-metal ion solution against a SPF-metal ion solution. The metal ions used were antimony(III), lanthanum(III), bismuth(III), germanium(IV), titanium(IV), niobium(V), tantalum(V), molybdenum(VI) and so on, in each metal ion alone or the coexistence of two metal ions. We confirmed that the combined use of niobium(V) and bismuth(III) was most effective. Based on these results, SPF and niobium(V) + bismuth(III) were chosen as a dye and metal ions, respectively, for further experiments.

Optimization of the conditions and absorption spectra

The effect of the $\mathrm{pH}$ on color development was investigated.

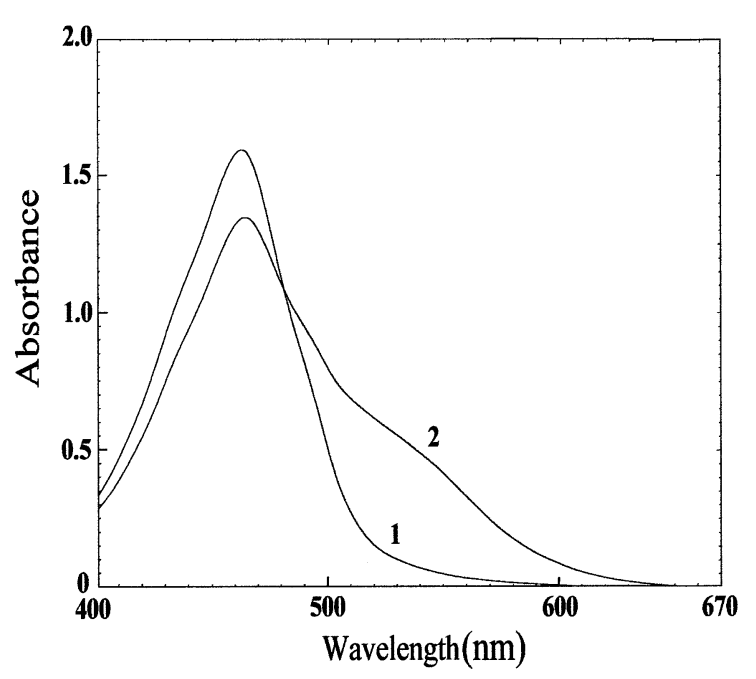

Fig. 2 Absorption spectra of HSA-SPF-metal ion and SPF-metal ion solutions. HSA, $10 \mu \mathrm{g} / \mathrm{ml}$; metal ion, $5.0 \times 10^{-5} \mathrm{~mol} \mathrm{dm}^{-3}$; SPF $1.0 \times 10^{-4} \mathrm{~mol} \mathrm{dm}^{-3}$; surfactant, $0.1 \% ; \mathrm{pH}, 2.0$; Curve 1 , SPF-metal ion solution; Curve 2, HSA-SPF-metal ion solution; reference, water.

A maximum and constant absorbance was observed at $\mathrm{pH} 1.8$ 2.5 by using a buffer solution of $0.1 \mathrm{~mol} \mathrm{dm}^{-3}$ sodium citrate- 0.1 mol dm${ }^{-3}$ hydrochloric acid; $0.1 \mathrm{~mol} \mathrm{dm}^{-3}$ glycine- $0.1 \mathrm{~mol} \mathrm{dm}^{-3}$ hydrochloric acid; $0.2 \mathrm{~mol} \mathrm{dm}^{-3}$ sodium acetate- $0.2 \mathrm{~mol} \mathrm{dm}^{-3}$ hydrochloric acid; or $0.2 \mathrm{~mol} \mathrm{dm}^{-3}$ potassium chloride- $0.2 \mathrm{~mol}$ $\mathrm{dm}^{-3}$ hydrochloric acid. As a consequence, $2.0 \mathrm{ml}$ of a $0.1 \mathrm{~mol}$ $\mathrm{dm}^{-3}$ sodium citrate- $0.1 \mathrm{~mol} \mathrm{\textrm {dm } ^ { - 3 }}$ hydrochloric acid buffer solution $(\mathrm{pH}$ 2.0) was used for $\mathrm{pH}$ adjustments, taking into account the removing of foreign ions.

In order to solubilize and stabilize the HSA-SPF-metal colored complex, the effect of various non-ionic surfactants, such as Triton X-305, Tween 20, Tween 60, Brij 35, hydroxypropyl cellulose, methyl cellulose (MC), PVA ( $n$ : 500, $n$ : 3500) and arabic gum as an anionic surfactant was systematically investigated. A maximum and constant absorbance was observed upon the addition of more than $0.5 \mathrm{ml}$ of a $1.0 \%$ PVA ( $n: 3500)$ solution to the final volume of $10 \mathrm{ml}$. However, the HSA-SPF-metal ion solution in the presence of PVA alone was unstable, resulting in gradual precipitation. The simultaneous use of the gum arabic solution together with PVA was most effective in terms of the sensitivity and stability among surfactants: arabic gum, MC, poly( $N$-vinylpyrrolidone), gelatin, etc. A maximum and constant absorbance was consequently observed upon the addition of more than $0.5 \mathrm{ml}$ of $1.0 \%$ [PVA $(n: 3500)+$ arabic gum](3:1) solution in final volume of $10 \mathrm{ml}$.

The effect of the concentration of the metal ion was examined by varying the molar ratio of niobium(V) to bismuth(III). A maximum and constant absorbance was observed when the molar ratio of niobium(V) to bismuth(III) was 1:1 and more than $0.25 \mathrm{ml}$ of a $1.0 \times 10^{-3} \mathrm{~mol} \mathrm{dm}^{-3}$ metal ion solution was added. The effect of the concentration of SPF was then examined, while maintaining fixed concentrations of HSA (50 $\mu \mathrm{g})$ and the metal ion solutions. The maximum absorbance was observed when the molar ratio of the metal ion to SPF was 1:2. Hence, all further work was done with final concentrations of $0.5 \mathrm{ml}$ of a $1.0 \times 10^{-3} \mathrm{~mol} \mathrm{dm}^{-3}$ metal solution and $1.0 \mathrm{ml}$ of a $1.0 \times 10^{-3} \mathrm{~mol} \mathrm{dm}^{-3} \mathrm{SPF}$ solution.

The effect of the sequence of adding the reagents on the absorbance values was examined. The same results were obtained even though the order of the addition of the reagents 
Table 1 Comparison of RSD between this method and PR method

\begin{tabular}{ccc}
\hline \multirow{2}{*}{$\begin{array}{c}\text { HSA } \\
(\mu \mathrm{g} / \mathrm{ml})\end{array}$} & RSD, \% \\
\cline { 2 - 3 } & 3.93 & PR method \\
\hline 1.0 & 1.82 & 9.13 \\
2.5 & 0.88 & 2.53 \\
10.0 & & 1.23 \\
\hline
\end{tabular}

Table 2 Reaction between several proteins and the SPF-metal complex

\begin{tabular}{lcc}
\hline \multicolumn{1}{c}{ Protein $^{\mathrm{a}}$} & This method, $\%^{\mathrm{b}}$ & PR method, $\%^{\mathrm{b}}$ \\
\hline HSA & 100 & 100 \\
Hemoglobin & 87 & 38 \\
Myoglobin & 112 & 53 \\
Transferrin & 83 & 115 \\
$\gamma$-Globulin & 86 & 85 \\
$\beta$-Globulin & 87 & 68 \\
$\alpha_{1}$-Acid glycoprotein & 52 & 35 \\
Fibrinogen & 63 & 58 \\
Bence-Jones protein & 62 & 30 \\
$\alpha_{1}$-Antitrypsin & 89 & 28 \\
Lactoferrin & 76 & 73 \\
\hline
\end{tabular}

a. Protein taken, $5 \mu \mathrm{g} / \mathrm{ml}$.

b. Percent with respect to HSA.

was varied. However, the influence of foreign substances was greatly decreased when a solution containing HSA was the last to be added to the reagent solution.

The color development in this reaction occurred instantaneously at room temperature and the absorbance value remained constant for at least $24 \mathrm{~h}$.

Figure 2 shows the absorption spectra of a HSA-SPF-metal ion solution and a SPF-metal ion solution under the standard procedure. The difference of the absorbance at $530 \mathrm{~nm}$ between both solutions was proportional to the concentration of HSA.

\section{Calibration curve}

A calibration curve for HSA was constructed by the standard procedure. A good linear relationship was observed over 1-15 $\mu \mathrm{g} / \mathrm{ml}$ of HSA. The relative standard deviation (RSD) for five runs of $1.0 \mu \mathrm{g} / \mathrm{ml}$ of HSA was $0.88 \%$. The molar absorptivity (E) was $2.77 \times 10^{6} \mathrm{dm}^{3} \mathrm{~mol}^{-1} \mathrm{~cm}^{-1}$. We compared RSD $(n=5)$ at a low concentration of HSA between the PR method and the proposed method because the reproducibility at a low concentration of HSA with PR method was poor, as stated above. As shown in Table 1, the proposed method was noticeably superior to the PR method regarding reproducibility at a low concentration of HSA. Therefore, this indicates that the proposed method gives accurate results in protein urinary assays. Furthermore, the response to different proteins was studied. The proposed designed method is advantageous in that the difference in the reactivity with various proteins is smaller than those in the PR method, as shown in Table 2. For example, this method recovered almost all Bence-Jones protein and $\alpha_{1-}$ antitrypsin, to which the detection sensitivity of the PR method was reported to below. Moreover, the sensitivity of the proposed method was about 2-times higher than that of the PR, BPB-In(III) ${ }^{9}$ and the Coomassie brilliant blue G(CBB) methods. ${ }^{10}$
Table 3 Effect of foreign substances on the assay of HSA

\begin{tabular}{llc}
\hline \multicolumn{1}{c}{ Substance } & $\mu \mathrm{g} / 10 \mathrm{ml}$ & Recovery, $\%$ \\
\hline $\mathrm{Fe}(\mathrm{II})$, sulfate & $2.8 \times 10$ & 85.8 \\
$\mathrm{Cu}(\mathrm{II})$, nitrate & $6.4 \times 10^{2}$ & 100.0 \\
$\mathrm{Zn}(\mathrm{II})$, chloride & $6.5 \times 10^{2}$ & 100.0 \\
$\mathrm{Ca}(\mathrm{II})$, chloride & $4.0 \times 10^{2}$ & 100.0 \\
$\mathrm{Mg}(\mathrm{II})$, chloride & $2.4 \times 10^{2}$ & 100.0 \\
$\mathrm{NaCl}$ & $5.8 \times 10^{3}$ & 100.0 \\
$\mathrm{KNO}_{3}$ & $1.0 \times 10^{4}$ & 100.0 \\
$\mathrm{~K}_{2} \mathrm{SO}_{4}$ & $1.7 \times 10^{4}$ & 100.0 \\
$\mathrm{KBr}_{\mathrm{KH}}{ }_{2} \mathrm{PO}$ & & 100.0 \\
$\mathrm{Oxalic}_{4}$ acid & $1.2 \times 10^{4}$ & 100.0 \\
Ascorbic acid & $2.3 \times 10^{4}$ & 85.7 \\
Glycine & $1.8 \times 10^{2}$ & 100.0 \\
Glucose & $5.3 \times 10^{4}$ & 100.0 \\
Urea & $7.5 \times 10^{3}$ & 100.0 \\
Uric acid & $1.8 \times 10^{4}$ & 100.0 \\
Caffeine & $6.0 \times 10^{3}$ & 100.0 \\
\end{tabular}

HSA, $10 \mu \mathrm{g} / \mathrm{ml}$; metal ion, $5.0 \times 10^{-5} \mathrm{~mol} \mathrm{dm}^{-3}$; SPF, $1.0 \times 10^{-4} \mathrm{~mol}$ $\mathrm{dm}^{-3}$; surfactant, $0.1 \%$; $\mathrm{pH}, 2.0$; reference, SPF-metal solution.

\section{Influence of foreign substances}

To assess its usefulness in urinary protein assays, the influence of various substances on the determination of HSA was examined. Among foreign substances, the presence of iron(II) and oxalic acid resulted in a slight decrease in the measurement. The absorbance values were hardly affected at their usual concentrations in the sample solution. Other substances exerted practically no effect on the absorbance, and the influence of other substances was extremely small compared to the PR method. The results are summarized in Table 3.

\section{Correlation with PR method}

The present method and the PR method (commercially available total protein assay kit, micro TP-test Wako, Wako Pure Chem. Co. Ltd.) were compared for human urine samples. A regression line was estimated using the least-squares method. There was no significant difference between the results obtained by the present method and the PR method for human urine samples $(r=0.945 ; Y=1.174 X+0.418 ; n=21)$, as shown in Fig. 3. The reason why the average value $(\bar{y}=4.74)$ determined by the present method was somewhat large with that $(\bar{x}=3.71)$ determined by the PR method is probably that the method is smaller than those in the PR method concerning the difference in the reactivity with various proteins, and the influence of foreign substances is extremely small compared with the PR method.

\section{Binding study for the reaction mechanism}

The reaction system employed in this study used a dye-metal complex, and is classified as a dye binding method, in which proteins are considered to interact with the dye part of the dyemetal complex.

Using double-reciprocal plots ${ }^{11}$ and van't Hoff plots, ${ }^{12}$ we spectrophotometrically determined the binding parameters ( $n$, number of binding sites; $K$, binding constant) and the thermodynamic parameters $\left(\Delta G^{0}\right.$, changes in Gibbs free energy; $\Delta H^{0}$, changes in enthalpy; $\Delta S^{0}$, changes in entropy) of the SPFmetal complex with HSA. In the binding reaction of the SPFmetal complex and HSA at $22^{\circ} \mathrm{C}, n=64.5, K=8.38 \times 10^{3} \mathrm{M}^{-1}$, $\Delta G^{0}=-22.34 \mathrm{~kJ} \mathrm{~mol}^{-1}, \Delta H^{0}=1.38 \mathrm{~kJ} \mathrm{~mol}^{-1}$ and $\Delta S^{0}=79.58 \mathrm{~J}$ $\mathrm{mol}^{-1} \mathrm{~K}^{-1}$ were obtained. Generally, hydrophobic bonding ${ }^{13}$ is 


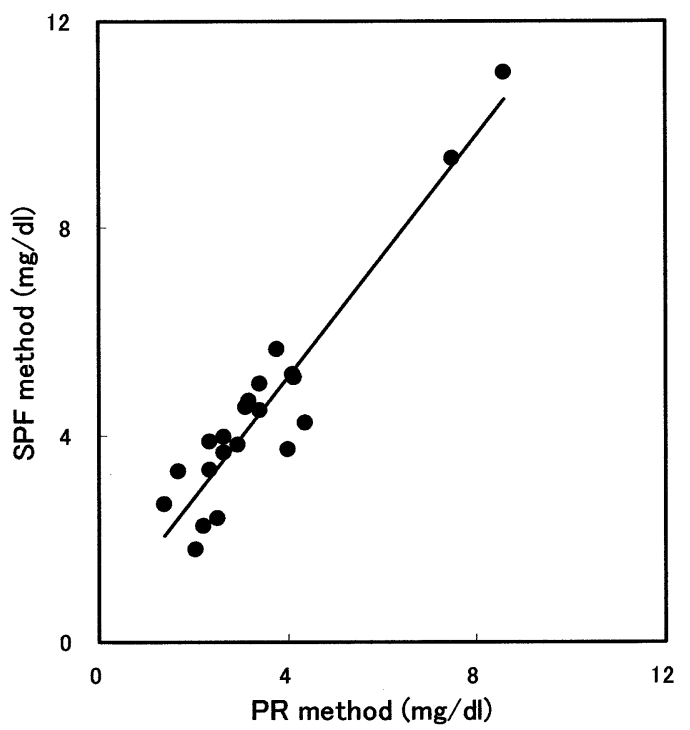

Fig. 3 Correlation between the results for urinary protein assays, as obtained by the PR method $(X)$ and the present method $(Y)$.

entropy-driven; its formation is an endothermic process, and the negative sign for $\Delta G^{0}$ indicates that the binding process is spontaneous. The binding process in this reaction system was endothermic ( $\Delta H^{0}$, positive), and the large increase in entropy resulted in a negative $\Delta G^{0}$. On the other hand, since the isoelectric point $(\mathrm{pI})$ of HSA is 4.8 , HSA exists as a cationic species, $[\mathrm{HSA}]^{\mathrm{n}+}$, at $\mathrm{pH}$ 2.0. Therefore, the association between the SPF-metal complex and HSA is primarily considered to be electrostatic between the positively charged regions of HSA and the negatively charged regions of the SPF. However, it is generally suggested that the interaction is hydrophobic between the hydrophobic regions of the SPF (aromatic rings) and the hydrophobic regions of HSA (side chains of hydrocarbons).

In conclusion, the proposed method offers many advantages for urinary protein assays. First, the difference in reactivity with various proteins on the proposed method was smaller than those in the PR method. Second, in the determination of HSA, this method was more sensitive than the PR method. Third, the method was superior to the PR method in reproducibility of the determination at low concentrations of protein. Fourth, there was a remarkable improvement in the influences of foreign substances by this method. Fifth, the reaction rate of this method was much faster than that of the PR method. And sixth, this method suggested that microalbuminurea was detectable while being highly sensitive and easy.

Though the study of the response of other proteins, for example type IV collagen, $\beta_{2}$-microglobulin and Tamm-Horsfall glycoprotein, is necessary, the proposed method will be available for total urinary protein assays and an earlier detection of microalbuminurea.

\section{References}

1. P. Zimmet, M. M. Alberte, and J. Shaw, Nature, 2001, 414, 782

2. C. E. Mogensen, J. Intern. Med., 2003, 254, 45.

3. F. B. Kingsbury and C. Clark, J. Lab. Clin. Med., 1926, 11, 981

4. O. Meumemans, Clin. Chim. Acta, 1960, 5, 757.

5. Y. Fujita, I. Mori, and S. Kitano, Bunseki Kgaku, 1983, 32, E 379 .

6. N. Watanabe, S. Kamei, A. Ohkubo, M. Yamanaka, S. Ohsawa, K. Makino, and K. Tokuda, Clin. Chem., 1986, 32,1551 .

7. J-L. Orsonneau, P. Douet, C. Massoubre, P. Lustenberger, and S. Bernard, Clin. Chem., 1989, 35, 2233.

8. H. Sano, Bull. Chem. Soc. Jpn., 1958, 31, 974.

9. H. Kosaka, K. Doi, K. Okamoto, and Y. Fujita, J. Clin. Lab. Inst. Reag., 2000, 23, 9.

10. M. M. Bradford, Anal. Biochem., 1976, 72, 248.

11. K. Sekiguchi and M. Iwatsuru, Yakuzaigaku, 1979, 39, 43.

12. Y. Fujita, I. Mori, and M. Toyoda, Anal. Sci., 1990, 6, 607.

13. G. Nemethy, Angew. Chem., Int. Ed. Engl., 1967, 6, 195. 